\title{
The role of entrepreneurship in achieving competitive advantage
}

\author{
Hoda Ahmed Ibraheem \\ Alhanof Mohammed Alshuraym \\ Arab East Colleges, Kingdom of Saudi Arabia
}

Keywords

entrepreneurship, business, SMEs, competitive advantage, administrators

\begin{abstract}
Despite the importance of promoting entrepreneurship in business activities to achieve a competitive advantage, a large proportion of business firms fail to make entrepreneurship a reality in their work. In addition, these constraints make it possible to gain a competitive advantage in the problems of the market in particular that modern markets are full of rivals and fast-paced changes in various variables. In light of this, the researcher carried out this study to investigate the role of entrepreneurship in achieving competitive advantage in SMEs. By using the descriptive-analytical approach, developing a questionnaire tool and distributing it to a sample of 100 administrators working in SMEs in Saudi Arabia. The results of the study showed that there is a positive relationship in the role of entrepreneurship in achieving competitive advantage in small and medium enterprises in the Kingdom of Saudi Arabia.
\end{abstract}

\section{The study Problem}

Companies face the need to be constantly nimble and flexible in today's fast-paced competitive environment. Although businesses are often able to assess a certain level of efficiency based on current technology, they are just as often left flat-footed in the face of new, novel technologies. Increased competition among businesses due to constant changes in the economy, resources, technology, demand and expectations of customers, labor and equipment costs, and limited opportunities (Zaid, 2013). In order to improve customer loyalty, this leads the management of businesses to explore how to enhance their resources, discover and leverage new opportunities, find more innovative ways and take effective steps to deliver new and high-service quality. In essence, this phase favorably influences the achievement of competitive advantage. In light of this, we can put the main question of the study: -What is the role of entrepreneurship in achieving competitive advantage?

The main question includes a number of sub-questions, the most important of which are the following:

What are the characteristics of entrepreneurs that are sources of competitive advantage?

What is the impact of entrepreneurship dimensions (creativity, innovation, risk-taking, and proactivity) in achieving a competitive advantage (service quality)?

What is the extent of participants' practice of the entrepreneurship dimensions?

Aim and objectives

This study aims to shed light on the role of entrepreneurship in achieving competitive advantage

\section{Introduction}

In modern business organizations, the ever-increase in global competition, scientific and technological advancement has motivated organizations to become an organization in several areas of business, product and service that achieves more of the dimensions of entrepreneurial orientation. Covin \& Miles, (1999), Ferrira, (2002), Dess et al., (2003), and Christensen, (2004), according to Burgelman et al., (1984), Entrepreneurship strengthens the imaginative and creative skills of employees of companies and leads them to improve their internal climate, policies, procedures, activities, capital, goods, and services in order to maximize their performance by creating new projects, taking advantage of new business opportunities and enhancing their competitiveness. Moreover, an entrepreneurship orientation will discern a risk-taking willingness to make full market profits. "In addition, Antoncic and Hisrich, 2003 note that: "Entrepreneurship practices are aimed at creating new business projects and developing new goods, 
services, innovations, and administrative strategies within existing organizations to broaden their activities".

\section{Definition of Entrepreneurship}

According to Brown, Davidsson, and Wiklund (2001), Entrepreneurship Management, utilizing Stevenson's description, found that "Entrepreneurial Management" could be described as entrepreneurial management practices that can help companies remain vital and contribute to the development of value for business and society. According to the explanation given by Kuhn (2010) using the concept of Stevenson, it is claimed that entrepreneurship is actually a method of management without regard to resources governed by the pursuit of opportunity. Entrepreneurial management is an established technique for changing further transparency in terms of internal services that leads to greater value for their money for customers and can be done through various processes, rewards, and funding (Oregon, 2010).

Entrepreneurship is a multidimensional term that incorporates multiple aspects (Low, 2001). This multidimensional nature of entrepreneurship has made it possible for scholars to conceptualize from a diverse viewpoint in several various ways. It is also worth noting that entrepreneurship has developed over the years as a philosophy and that its conceptualization has changed as well. For example, entrepreneurship was used in the Middle Ages to apply to the capacity of a person to handle large production projects (Padilla and Cachanosky, 2016). In this context, the emphasis was on the ability of the individual to handle the projects using the resources available, but not on the individual's capacity to take risks.

Therefore, a typical entrepreneur was a cleric or a person who was responsible for managing great architectural works and fortifying cathedrals, abbeys, and public buildings. In the 17th century, as people began linking entrepreneurship with risks, this view shifted. As conceptualized throughout this time, an entrepreneur was a person licensed to supply a specified product or perform a service by the government, and he received a profit or loss through this contractual arrangement. This was in line with the 17thcentury theory of Richard Cantillion that such an entrepreneur could purchase things at a certain price and sell them at a different yet uncertain price as a risk-taker. In line with this view, farmers, artisans, traders, and other sole owners illustrated entrepreneurs throughout this age. Businessmen were seen as venture capitalists later in the 18th century (Rahatullah Khan, 2013).

In the 19th and 20th centuries, this perception shifted somewhat because entrepreneurship was primarily regarded from an economic viewpoint and not differentiated from management. An entrepreneur was therefore defined as an individual who conducted and administered a business for personal profit and charged prices for the products used by the company; paid for the use of the land and for the money, as well as for the employing specific services. An entrepreneur was also seen as an employee who could contribute to the preparation, management, and organization of the business with personal initiative, creativity, and ability. This person may assume the chance of gaining a benefit or risking a loss resultant from uncontrollable and unforeseen circumstances (Bridge, 2017). In the 20th and 21st centuries, the idea of entrepreneurship was applied to the concept of creativity.

Nowadays, Entrepreneurs are seen as people with the potential to revolutionize production patterns by leveraging an innovation. Others see an entrepreneur as a business individual who begins (builds), creates, and manages a business enterprise that risks capital, effort, and time (Al Qudah, 2018). Additionally, Baron and Henry (2010) define entrepreneurship as referring to the person who uses its attributes, like risk-taking, ingenuity, imagination, and the ability to organize and schedule activities to execute ideas in order to achieve a certain purpose.

\section{Competitive Advantage}

In a world where market rivalry is highly intense, businesses need to improve their practices, personnel, procedures, and strategies in order to develop and improve their competitive advantage. Moreover, developments in market phenomena and competitive conditions nowadays have a huge effect on businesses to develop specific competition or competitive advantage (Thompson et al., 2008; Rungwitoo, 2012). One of the strongest priorities of companies is to maintain and maintain a competitive advantage in order to be competitive with rivals to attract new buyers (Javadi, 2011). 
The competitive advantage is the ability of a company to establish a defensible role over its rivals (Porter, 1985). Competitive advantage implies that one company will compete with its competition if two or more companies compete in the same market at the same time (Grant, 1998). Competitive advantage is the comprehensive skills that enable a company to distinguish itself from its rivals and is the product of critical decision-making in administration (Tracey et al., 1999; Li et al., 2004). It is the thing in the minds of clients that separates your business from its rivals. A business or manager needs to have a strong competitive advantage and convey that advantage to its clients and markets (Zaid, 2013).

The competitive advantage is the ability of a company to function, execute, innovate, and implement novel products and services in forms that cannot be matched by rivals (Kotler, 2000). A business must have sustainable values for clients in addition to creating a competitive advantage. An organization is said to have a competitive advantage When a company implements a value-creating strategy that is not adopted by its existing or future rivals at the same time (Clulow, Gerstman, \& Barry, 2003).

It has been noted and believed that Entrepreneurship and competitive advantage are directly or indirectly related to the performance of the company, here are the previous studies that talked about Entrepreneurship and its connection to a company's competitive advantage:

Dalvi \& Ahangaran (2014) explored the effects of entrepreneurship and sustainable competitive advantage by evaluating the merits of marketing and innovation potential in appliances companies in Isfahan Province. Data were collected through a questionnaire using statistical software including the SPSS statistical test of normality test of data distribution (Kolmogorov - Smirnov test), regression, and ANOVA was examined. The study sample included all the managers of the hardware companies in Isfahan governorate, whose number is estimated at 91 . All census methods were used regardless of the total population. The results indicated that there is a significant relationship between entrepreneurship and competitive advantage in appliances firms in Isfahan province.

Zaridis (2016) illustrated some aspects of the entrepreneur and the SME that are sources of competitive advantage. In resource-based words, a plethora of tools and competencies have been proposed as sources of competitive advantage and new ones are constantly added. The hierarchy of sources of competitive advantage about their sustainability seems to be struggling. Some variables, including company size, management, ownership, data relating to the sustainability and competitiveness of small and medium-sized companies, revenue, profitability, liquidity, lack of trained staff, data and market knowledge on distribution networks, possible fundraising, use of innovation or new technology, organizational structure, control of the capital, networking, and clustering, play an important role. These factors affect the company size of SMEs, such as entrepreneurial characteristics, management techniques, the influence of the external climate, and SME attributes, which are among the factors that make up the features of a good small business. There is no variation between the failure of SMEs and success. There are three types of failures listed, apart from environmental factors: functional expertise, managerial skills, and managerial behavior, linked to the characteristics of entrepreneurs and SMEs.

$\mathrm{Ab}$ Rahman (2014) contributed to the understanding of SMEs and firm performance within the business by drawing attention to the crucial factors affecting its success and further providing an integrated structure for evaluating the performance of SMEs. It is suggested that it relies on resourcebased view theory as well as incorporating perspectives from Porter's theory into an integrative framework of firm success and factors affecting it. The proposed structure has made it possible to recognize the factors influencing the success of SMEs and to capture holistic organizational performance within the business.

Haseeb et al. (2019) explored the importance of social and technological challenges in achieving a sustainable competitive advantage and sustainable performance of the industry. To achieve this goal, firsthand data from Malaysian SMEs have been obtained. Opinions on the roles of social and technological obstacles in achieving a sustainable competitive advantage and sustainable business results were favored among managers of these SMEs. To collect data, an email survey was carried out. A total of 500 questionnaires have been distributed to SME management personnel. By simple random sampling, questionnaires were distributed. The survey's results showed that social and technological challenges played a major role in improving sustainable competitive advantage and sustainable business efficiency through the use of structural equation modeling. In addition, strategic alignment has been a critical factor 
in representing the positive position of social and technical influences in sustainable competitive advantage. The study's results were helpful to practitioners and will allow their approaches to representing sustainable competitive advantages and sustainable business results.

Murniningsih \& Hanafi (2020) explored the mediation impact of innovation to improve the competitive advantage of small and medium enterprises in the Magelang market by affecting entrepreneurial leadership and information technology and communication. A survey in the form of a questionnaire was used. The population was the employees of the small and medium enterprises in the Magelang area, and the approach of sample collection takes the form of non-probabilistic sampling using a purposeful sampling technique, 105 respondents were in the survey. In testing hypotheses and through the Warp PLS software, the research instrument used Structural Equation Modeling (SEM). The test results showed that in promoting competitive advantage in small and medium enterprises, entrepreneurial leadership and information technology and communication are extremely significant.

Sulistyo and Ayuni (2020) explored the effect on innovation and efficiency capabilities of entrepreneurial orientation and social capital in gaining sustainable competitive advantage of SMEs. Descriptive and explanatory methodologies are used. The study sample consisted of owners of SME handicrafts in Semarang, Jepara, Kudus, with up to 254 participants. Sampling is carried out on SMEs that have been running for at least five years, have employees of more than 10 individuals, and still operate to date. Via closed and open questionnaires and interviews, data was gathered using the survey process. Using the structural equation method of the AMOS software, data analysis was performed. The findings showed that there is a major impact on entrepreneurship and performance capabilities between entrepreneurial orientation and social capital. The potential for creativity has a huge effect on performance enhancement and the competitive advantage of SMEs.

\section{Literature Review}

Small and medium-sized enterprises (SMEs) are the largest industry of all countries. It has a major position in any country's Gross Domestic Product (GDP) (Mckague et al., 2011). In the Kingdom of Saudi Arabia, there is an understanding that supports for SMEs is an important contributor to economic development and growth. This support is provided by the General Authority to small and medium-sized enterprises; it named one of its objectives in Arabic "Monshaat" to increase SME participation in GDP by 20 percent of GDP to 35 percent by 2030 (Alghanmi, 2020).

The world of business is characterized by high uncertainty and rapid change define. In order to promote entrepreneurship and creativity and to create a competitive edge in the industry, the specific problems in the world of business requirements for small and medium enterprises need to be prepared. By making it stand out from rivals in one or more aspects, including, though not limited to the launch of new goods or services, a competitive advantage helps a company. It is not an easy endeavor to become competitive in the market; it requires paying emphasis on the significance of entrepreneurship and innovation in all organizational functions and procedures (Epetimehin, 2011).

In addition, the competitive advantage is one of the vital topics for continuity. This importance lies in that it enables a business firm to exhibit superior performance in one aspect or more in a manner that is considered superior to that of other competitors. Attaining a competitive advantage requires a firm to focus on some strategies and improving the firm's public image. This value lies in the fact that it allows a company to exhibit superior performance in one element or more in a way that is considered superior to that of other rivals. A company needs to concentrate on some policies and improve the public image of the company to achieve a competitive advantage (Alghanimi, 2020).

\section{Research Methodology}

The study adopted the descriptive-analytical method of the random sample method, the study was limited to a sample of small and medium-sized companies consist of (100) employees that have been operating for at least five years, employing more than 10 people, and are still in existence today In the Kingdom of Saudi Arabia. A special questionnaire has been designed for distribution to this sample, including a set of determinants that represent gender, age educational level, number of years of experience various and interrelated questions, distributed as shown in table (1) below. 
Table (1): Distribution of the study sample in SMEs in KSA

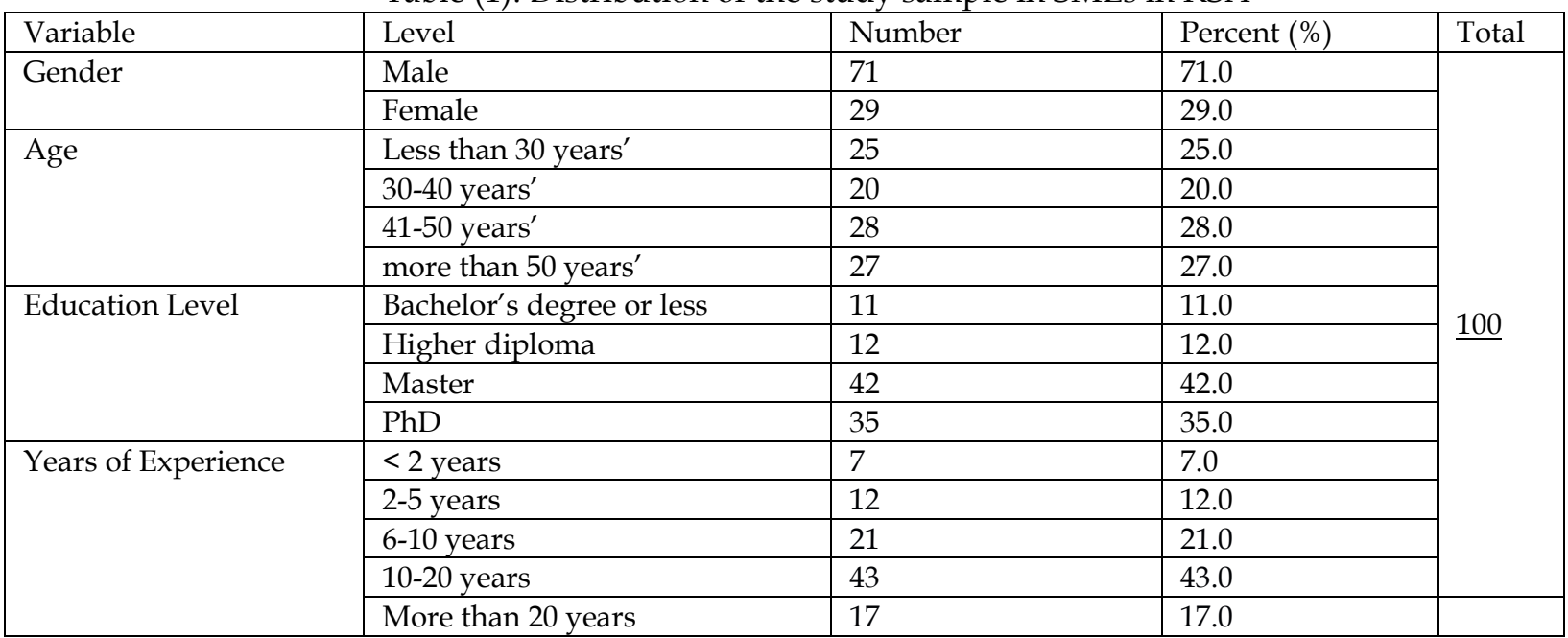

According to Table (1) results, it can be noticed that the study sample consists of both gender (males and females). Majority of the sample were male (71\%), while the female category constitutes $(29 \%)$ of the total sample. This percentage gives an indication that the sample is representative of society and that it takes into account the point of view of females and males alike, but perhaps the slight increase in the number of male participants is that men are more practicing jobs and works than females in the traditional Saudi society.

It is evident from Table No. (1) that the age group most participating in this survey was (41-50 years) by $(28 \%)$, followed by (27\%) respondents (over 50 years old), then followed by the age group (less than 30 years old) By (25\%), and finally the age group (30-40 years) by (20\%), and this confirms that (28\%) a percentage of managers in SMEs in KSA who enjoy the youth age group.

Moreover, it appears from Table (1),with regard to the (Education Level) variable, that the category most involved in the survey is the (Master) category with a percentage $(42 \%)$, followed by the $(\mathrm{PhD})$ category and with a percentage (35\%), and the (Higher diploma) category came before The last percentage $(12 \%)$, and finally, the least participation in the survey was the category (Bachelor degree or less) with a percentage $(11 \%)$, this confirms that the largest percentage of the study sample is the (Master) category of managers in SMEs in KSA, This indicates that business managers in these companies enjoy a high level of education

Finally, Table (1) indicates according to the (Years of Experience) variable, that the category most participating in the survey is (10-20 years) with a percentage (43\%), then it is followed by (6-10 years) with a percentage $(21 \%)$. The category (More than 20 years) and a percentage $(17 \%)$, and the category $(2-5$ years) with a percentage $(12 \%)$, Finally, the least participation in the survey was the category (Less than two years) by a percentage $(7 \%)$. This confirms that the largest percentage of the study sample is the category (10-20 years) of managers in SMEs in KSA, which indicates that Business managers in these companies are highly experienced and have high competencies and experiences.

\section{Analysis the Result}

Main question: What is the role of entrepreneurship in achieving competitive advantage?

To answer this question, the descriptive summary (means and standard deviation) of the responses to the statements measuring the role of entrepreneurship in achieving competitive advantage was calculated from the point of view of managers in SMEs in KSA and for the variables as a whole. Table (5) below illustrates those values, where those values are arranged in descending order according to their calculated arithmetic means. 
Table (5) Descriptive Summary (means and standard deviation) for the role of entrepreneurship in achieving competitive advantage in SMEs in KSA

\begin{tabular}{|l|l|l|l|l|l|}
\hline $\begin{array}{l}\text { Number } \\
\text { the field }\end{array}$ & The field & Means & $\begin{array}{l}\text { Standard } \\
\text { deviations }\end{array}$ & $\begin{array}{l}\text { Practice's } \\
\text { degree }\end{array}$ & $\begin{array}{l}\text { The } \\
\text { rank }\end{array}$ \\
\hline 3 & Creativity & 3.96 & 0.55 & High & 1 \\
\hline 2 & Innovation & 3.86 & 0.41 & High & 2 \\
\hline 5 & Pro-activity & 3.79 & 0.53 & High & 3 \\
\hline 1 & competitive advantage (service quality) & 3.78 & 0.35 & High & 4 \\
\hline 4 & Risk-taking & 3.64 & 0.47 & Medium & 5 \\
\hline \multicolumn{2}{|l|}{ The tool as a whole } & 3.82 & 0.34 & \multicolumn{2}{|c|}{ High } \\
\hline
\end{tabular}

Table Number. (5) shows that the means of the approval of the research sample for the role of entrepreneurship in achieving competitive advantage from the viewpoint of managers in SMEs in KSA ranged between (3.64 - 3.96). In order to determine the paragraphs according to the fields they fall means and standard deviations were calculated for areas of the role of entrepreneurship in achieving competitive advantage from the viewpoint of managers in SMEs in KSA It ranged for each paragraph separately. and an arrangement was made for the paragraphs of each dimension, and below is a presentation of the results according to the fields:

The First Question: What are the characteristics of entrepreneurs that are sources of competitive advantage?

The First Scale: Competitive advantage (service quality)

This field included (9) paragraphs that measure the characteristics of entrepreneurs that are sources of competitive advantage from the viewpoint of managers in SMEs in KSA, and Table No. (6) shows this.

Table (6) below illustrates those values, where those values are arranged in descending order according to their calculated arithmetic means.

Table (6) Descriptive Summary (means and standard deviation) for the competitive advantage (service quality) in SMEs in KSA

\begin{tabular}{|l|l|l|l|l|l|}
\hline$\#$ & The paragraphs & Means & $\begin{array}{l}\text { Standard } \\
\text { deviations }\end{array}$ & $\begin{array}{l}\text { Practice's } \\
\text { degree }\end{array}$ & $\begin{array}{l}\text { The } \\
\text { rank }\end{array}$ \\
\hline 1 & $\begin{array}{l}\text { The company provides its services with competitive } \\
\text { prices }\end{array}$ & 3.93 & 0.79 & High & 1 \\
\hline 6 & $\begin{array}{l}\text { The company is an entrepreneur in providing } \\
\text { services before its rivals. }\end{array}$ & 3.89 & 0.86 & High & 2 \\
\hline 2 & $\begin{array}{l}\text { company services and prices are adaptable } \\
\text { according to supply and demand. }\end{array}$ & 3.87 & 0.69 & High & 3 \\
\hline 5 & $\begin{array}{l}\text { The company works provide services which } \\
\text { include new additional features. }\end{array}$ & 3.83 & 0.91 & High & 4 \\
\hline 3 & $\begin{array}{l}\text { The company provides offers on its services prices. } \\
\text { The company quickly responses to customer } \\
\text { complaints. }\end{array}$ & 3.7 .77 & 0.83 & High & 5 \\
\hline 9 & $\begin{array}{l}\text { The company evaluates the quality of its services } \\
\text { with constant development to improve its } \\
\text { competitive position in the market. }\end{array}$ & 3.65 & 0.82 & Migh & 6 \\
\hline 4 & $\begin{array}{l}\text { The company seeks to provide new services. } \\
\text { The company stimulates the research and } \\
\text { development (R\&D) to provide services in } \\
\text { accordance with the customers' needs. }\end{array}$ & 3.47 & 0.91 & Medium & 9 \\
\hline 8 & & 3.61 & 0.91 & Medium & 8 \\
\hline the scale as a whole & High \\
\hline
\end{tabular}

It can be noticed from Table (6) above that the arithmetic means that measure the competitive advantage (service quality) in SMEs in KSA are high and medium, ranging between (3.47 - 3.93). Moreover, the overall mean for this section was (3.78) which shows that most of the study sample highly agrees with the items of this part of the study. 
It can be noticed that item (1), which states that: "The company provides its services with competitive prices,", represents the highest agreed mean statement $(3.93$, Std. $=0.79)$ and was followed by item (6) secondly in which it stated that: "The company is an entrepreneur in providing services before its rivals" with a mean $(3.89$, Std. $=0.86)$, thirdly item $(4)$ in which it stated that: "The company seeks to provide new services " with a mean $(3.61$, Std. $=0.91)$ and fourthly item $(8)$ which stated that: "The company stimulates the research and development $(\mathrm{R} \& \mathrm{D})$ to provide services in accordance with the customers' needs " with a mean $(3.47$, Std. $=0.91)$

The second question: What is the impact of entrepreneurship dimensions (creativity, innovation, risktaking, and pro-activity) in achieving a competitive advantage (service quality)?

To detect the impact of entrepreneurship dimensions (creativity, innovation, risk-taking, and proactivity) in achieving a competitive advantage (service quality), a multiple linear regression test was used.

Table (7) Shows the multiple linear regression test for the impact of entrepreneurship dimensions in achieving a competitive advantage.

\begin{tabular}{|l|l|l|l|l|l|l|l|l|l|}
\hline $\begin{array}{l}\text { the impact of } \\
\text { entrepreneurship } \\
\text { dimensions in } \\
\text { achieving a } \\
\begin{array}{l}\text { competitive } \\
\text { advantage }\end{array}\end{array}$ & $\begin{array}{l}\text { The } \\
\text { Source } \\
\text { of change }\end{array}$ & $\begin{array}{l}\text { Sum of } \\
\text { squares }\end{array}$ & $\begin{array}{l}\text { Degrees } \\
\text { of } \\
\text { freedom }\end{array}$ & $\begin{array}{l}\text { Mediu } \\
\mathrm{m} \\
\text { Sum } \\
\text { of } \\
\text { squares }\end{array}$ & $\begin{array}{l}\text { The } \\
\text { coefficient } \\
\text { of } \\
\text { determina- } \\
\text { tion }\left(\mathrm{R}^{2}\right)\end{array}$ & $\begin{array}{l}\text { Coefficient } \\
\text { of } \\
\text { Correlation } \\
(\mathrm{R})\end{array}$ & $\begin{array}{l}\text { Value } \\
\mathrm{F}\end{array}$ & $\begin{array}{l}\text { The } \\
\text { signify- } \\
\text { cance } \\
\text { level }\end{array}$ & $\begin{array}{l}\text { The statist- } \\
\text { ical }\end{array}$ \\
\cline { 2 - 8 } & $\begin{array}{l}\text { Regression } \\
\text { The error } \\
\text { Total }\end{array}$ & $\begin{array}{l}10.356 \\
1.711 \\
12.067\end{array}$ & $\begin{array}{l}4 \\
95\end{array}$ & $\begin{array}{l}2.589 \\
0.018\end{array}$ & 0.858 & $0.926 \mathrm{a}$ & 143.743 & $0.000 \mathrm{~b}$ & $\begin{array}{l}\text { Statistical } \\
\text { significance }\end{array}$ \\
\hline
\end{tabular}

The previous table Number (7) shows that there is impact of entrepreneurship dimensions (creativity, innovation, risk-taking, and pro-activity) in achieving a competitive advantage (service quality) at a significance level of $(a \leq 0.05)$ and this is confirmed by the value of a significance level equal to (143.743) as it is less than 0.05 . Depending on the table (7), the correlation coefficient (0.926) between the dependent variable (competitive advantage) and the independent variables (Pro-activity, Innovation, Risk-taking, Creativity) was reached, and the determination coefficient was (0.858). This means that the dependent variable explains a percentage $(85.8 \%)$ of the dependent variables.

Table (8) Multiple linear regression test of the second question linear equation coefficients

\begin{tabular}{|c|c|c|c|c|c|c|}
\hline \multicolumn{7}{|c|}{ Coefficients } \\
\hline \multirow{2}{*}{\multicolumn{2}{|c|}{$\begin{array}{|lr|}\text { The dimensions of } \\
\text { the } \\
\text { variable }\end{array}$}} & \multicolumn{2}{|c|}{ Unstandardized Coefficients } & \multirow{2}{*}{$\begin{array}{c}\text { Standardized } \\
\text { Coefficients } \\
\text { Beta } \\
\end{array}$} & \multirow[b]{2}{*}{ Value $\mathrm{t}$} & \multirow[b]{2}{*}{ Sig. } \\
\hline & & B & Std. Error & & & \\
\hline & (Constant) & 0.140 & 0.159 & & 0.879 & 0.382 \\
\hline & Innovation & 0.341 & 0.040 & 0.409 & 8.532 & 0.000 \\
\hline & Creativity & 0.230 & 0.030 & 0.369 & 7.748 & 0.000 \\
\hline & Risk-taking & 0.207 & 0.030 & 0.283 & 6.824 & 0.000 \\
\hline & Pro-activity & 0.187 & 0.026 & 0.285 & 7.074 & 0.000 \\
\hline
\end{tabular}

The previous table Number (8) shows that there is impact of entrepreneurship dimensions (creativity, innovation, risk-taking, and pro-activity) in achieving a competitive advantage (service quality) at a significance level of $(a \leq 0.05)$, Depending on the table (8) that shows the values of $t$ for the independent variables (Pro-activity, Innovation, Risk-taking, Creativity), all of which are statistically significant, at the level of statistical significance (0.000), Which indicates that there is an effect of entrepreneurship dimensions in achieving a competitive advantage (service quality).

Therefore, the multiple linear regression equation is as follows:

Competitive advantage (service quality) $=0.140+(0.341) *$ (Innovation) $+(0.230) *$ (Creativity) + $(0.207) *$ (Risk-taking $)+(0.187) *$ (Pro-activity $)$ 
The Third Question: What is the extent of participants' practice of the entrepreneurship dimensions?

To answer this question, the descriptive summary (means and standard deviation) of the responses to the statements measuring the extent of participants' practice of the entrepreneurship dimensions was calculated from the point of view of managers in SMEs in KSA.

The Second Scale: entrepreneurship dimensions.

The First Field: Innovation

This field included (7) paragraphs that measure the extent of participants' practice of the entrepreneurship dimensions from the viewpoint of managers in SMEs in KSA, and Table No. (9) shows this.

Table (9) below illustrates those values, where those values are arranged in descending order according to their calculated arithmetic means

Table (9) Descriptive Summary (means and standard deviation) for the entrepreneurship dimensions (Innovation) in SMEs in KSA.

\begin{tabular}{|c|c|c|c|c|c|}
\hline \# & The paragraphs & Means & $\begin{array}{l}\text { Standard } \\
\text { deviations }\end{array}$ & $\begin{array}{l}\text { Practice's } \\
\text { degree }\end{array}$ & $\begin{array}{l}\text { The } \\
\text { rank }\end{array}$ \\
\hline 6 & $\begin{array}{l}\text { The company seeks to benefit from technology in order to } \\
\text { provide better services. }\end{array}$ & 4.05 & 0.64 & High & 1 \\
\hline 5 & $\begin{array}{l}\text { The company provides training courses for employees to } \\
\text { reach innovation and excellence. }\end{array}$ & 4.03 & 0.86 & High & 2 \\
\hline 1 & $\begin{array}{l}\text { The company strongly emphasizes research and } \\
\text { development R\&D and innovation instead of focusing on } \\
\text { the marketing of current services. }\end{array}$ & 3.92 & 0.82 & High & 3 \\
\hline 3 & $\begin{array}{l}\text { Over the past years, the company introduced many new } \\
\text { services. }\end{array}$ & 3.90 & 0.85 & High & 4 \\
\hline 7 & $\begin{array}{l}\text { The company priorities which are taken into account are in } \\
\text { continuous growth and stability }\end{array}$ & 3.81 & 0.91 & High & 5 \\
\hline 2 & The changes in services in the company are quite dramatic. & 3.79 & 0.83 & High & 6 \\
\hline 4 & $\begin{array}{l}\text { Senior management philosophy in the company } \\
\text { emphasizes the development of services regardless of their } \\
\text { costs. }\end{array}$ & 3.52 & 0.85 & Medium & 7 \\
\hline \multicolumn{2}{|c|}{ the field as a whole } & 3.86 & 0.41 & \multicolumn{2}{|l|}{ High } \\
\hline
\end{tabular}

It can be noticed from Table (9) above that the arithmetic means that measure the entrepreneurship dimensions (Innovation) in SMEs in KSA are high and medium, ranging between (3.52 - 4.05). Moreover, the overall mean for this section was (3.86) which shows that most of the study sample highly agrees with the items of this part of the study.

It can be noticed that item (6), which states that: "The company seeks to benefit from technology in order to provide better services,", represents the highest agreed mean statement 4.05 , Std. $=0.64$ ) and was followed by item (5) secondly in which it stated that: "The company provides training courses for employees to reach innovation and excellence " with a mean $(4.03$, Std. $=0.86)$, thirdly item (2) in which it stated that: " The changes in services in the company are quite dramatic " with a mean $(3.79$, Std. $=0.83)$ and fourthly item (4) which stated that: "Senior management philosophy in the company emphasizes the development of services regardless of their costs' needs " with a mean $(3.52$, Std. $=0.85)$

\section{The Second Field: Creativity}

This field included (5) paragraphs that measure the extent of participants' practice of the entrepreneurship dimensions from the viewpoint of managers in SMEs in KSA, and Table No. (10) shows this.

Table (10) below illustrates those values, where those values are arranged in descending order according to their calculated arithmetic means

Table (10) Descriptive Summary (means and standard deviation) for the entrepreneurship dimensions (Creativity) in SMEs in KSA. 


\begin{tabular}{|l|l|l|l|c|c|}
\hline$\#$ & The paragraphs & Means & $\begin{array}{l}\text { Standard } \\
\text { deviations }\end{array}$ & $\begin{array}{c}\text { Practice's } \\
\text { degree }\end{array}$ & $\begin{array}{c}\text { The } \\
\text { rank }\end{array}$ \\
\hline 1 & $\begin{array}{l}\text { The company 1 benefits from the ideas of workers in } \\
\text { solving problems. }\end{array}$ & 4.07 & 0.72 & High & 1 \\
\hline 5 & $\begin{array}{l}\text { The company is keen on research and development (R\&D) } \\
\text { and provides services that comply with customer needs. }\end{array}$ & 4.02 & 0.84 & High & 2 \\
\hline 4 & $\begin{array}{l}\text { The company encourages the teamwork approach to } \\
\text { produce new ideas. }\end{array}$ & 3.94 & 0.81 & High \\
\hline 2 & $\begin{array}{l}\text { The company encourages new ideas from any worker } \\
\text { regardless of his/her status in the company. }\end{array}$ & 0.93 & High \\
\hline 3 & $\begin{array}{l}\text { The company gives great attention to devise services and } \\
\text { new processes. }\end{array}$ & 3.82 & 0.89 & High & 5 \\
\hline the field as a whole & 3.96 & 0.55 & High \\
\hline
\end{tabular}

It can be noticed from Table (10) above that the arithmetic means that measure the entrepreneurship dimensions (Creativity) in SMEs in KSA are high, ranging between $(3.82-4.07)$. Moreover, the overall mean for this section was (3.96) which shows all of the study sample highly agrees with the items of this part of the study.

It can be noticed that item (1), which states that: "The company 1 benefits from the ideas of workers in solving problems,", represents the highest agreed mean statement $(4.07, \mathrm{Std} .=0.72)$ and was followed by item (5) secondly in which it stated that: "The company is keen on research and development (R\&D) and provides services that comply with customer needs " with a mean $(3.89$, Std. $=0.86)$, thirdly item (2) in which it stated that: "The company encourages new ideas from any worker regardless of his/her status in the company " with a mean $(3.91$, Std.= 0.93) and fourthly item (3) which stated that: "The company gives great attention to devise services and new processes " with a mean $(3.82$, Std. $=0.89)$

\section{The Third Field: Risk-taking}

This field included (5) paragraphs that measure the extent of participants' practice of the entrepreneurship dimensions from the viewpoint of managers in SMEs in KSA, and Table No. (11) shows this.

Table (11) below illustrates those values, where those values are arranged in descending order according to their calculated arithmetic means

Table (11) Descriptive Summary (means and standard deviation) for the entrepreneurship dimensions (Risk-taking) in SMEs in KSA.

\begin{tabular}{|l|l|l|l|l|l|}
\hline$\#$ & \begin{tabular}{l} 
The paragraphs \\
\hline 2
\end{tabular} & $\begin{array}{l}\text { Theans } \\
\text { of outputs. }\end{array}$ & $\begin{array}{l}\text { Standard } \\
\text { deviations }\end{array}$ & $\begin{array}{l}\text { Practice's } \\
\text { degree }\end{array}$ & $\begin{array}{l}\text { The } \\
\text { rank }\end{array}$ \\
\hline 1 & $\begin{array}{l}\text { The company is a risk-taker with the opportunities } \\
\text { associated with risks. }\end{array}$ & 3.84 & 0.88 & High & 1 \\
\hline 5 & $\begin{array}{l}\text { The company practice the “wait and see" position to } \\
\text { minimize risk. }\end{array}$ & 3.67 & 0.73 & Medium & 3 \\
\hline 4 & $\begin{array}{l}\text { In general, the company emphasizes high-risk projects } \\
\text { with uncertain returns. }\end{array}$ & 3.66 & 0.76 & Medium & 4 \\
\hline 3 & $\begin{array}{l}\text { The company seeks to seize opportunities and search for } \\
\text { new markets. }\end{array}$ & 3.50 & 0.75 & Medium & 5 \\
\hline the field as a whole & 3.64 & 0.47 & Medium \\
\hline
\end{tabular}

It can be noticed from Table (11) above that the arithmetic means that measure the entrepreneurship dimensions (Risk-taking) in SMEs in KSA are high and medium, ranging between (3.50 - 3.98). Moreover, the overall mean for this section was (3.64) which shows that most of the study sample highly agrees with the items of this part of the study. 
It can be noticed that item (2), which states that: "The company decisions are risky in spite of the uncertainty of outputs,", represents the highest agreed mean statement $(3.98$, Std. $=0.86)$ and was followed by item (1) secondly in which it stated that: "The company is a risk-taker with the opportunities associated with risks " with a mean $(3.84$, Std.= 0.88), thirdly item (4) in which it stated that: "In general, The company emphasizes high-risk projects with uncertain returns " with a mean $(3.66$, Std.=0.76) and fourthly item (3) which stated that: "The company seeks to seize opportunities and search for new markets " with a mean $(3.50$, Std. $=0.75)$

\section{The Fourth Field: Pro-activity}

This field included (5) paragraphs that measure the extent of participants' practice of the entrepreneurship dimensions from the viewpoint of managers in SMEs in KSA, and Table No. (12) shows this.

Table (12) below illustrates those values, where those values are arranged in descending order according to their calculated arithmetic means

Table (12) Descriptive Summary (means and standard deviation) for the entrepreneurship dimensions (Pro-activity) in SMEs in KSA.

\begin{tabular}{|l|l|l|l|l|l|}
\hline$\#$ & The paragraphs & Means & $\begin{array}{l}\text { Standard } \\
\text { deviations }\end{array}$ & $\begin{array}{l}\text { Practice's } \\
\text { degree }\end{array}$ & $\begin{array}{l}\text { The } \\
\text { rank }\end{array}$ \\
\hline 4 & $\begin{array}{l}\text { The company works on providing services that include } \\
\text { new features and different improvements more than } \\
\text { competitors. }\end{array}$ & 4.06 & 0.90 & High \\
\hline 5 & $\begin{array}{l}\text { The company is fast-growing towards achieving its main } \\
\text { objectives. }\end{array}$ & 3.96 & 0.76 & High & 2 \\
\hline 2 & $\begin{array}{l}\text { In general, the company is the first mover in introducing } \\
\text { new services. }\end{array}$ & 3.82 & 0.77 & High & 3 \\
\hline 3 & $\begin{array}{l}\text { The company seeks for customers-satisfaction in a way } \\
\text { beyond the size of the possibilities available. }\end{array}$ & 3.75 & 0.82 & High & 4 \\
\hline 1 & $\begin{array}{l}\text { The company seeks to provide new services before its } \\
\text { competitors. }\end{array}$ & 3.47 & 0.79 & Medium & 5 \\
\hline the field as a whole & 3.79 & 0.53 & High \\
\hline
\end{tabular}

It can be noticed from Table (12) above that the arithmetic means that measure the entrepreneurship dimensions (Pro-activity) in SMEs in KSA are high and medium, ranging between (3.47 - 4.06). Moreover, the overall mean for this section was (3.79) which shows that most of the study sample highly agrees with the items of this part of the study.

It can be noticed that item (4), which states that: "The company works on providing services that include new features and different improvements more than competitors,", represents the highest agreed mean statement $(4.06$, Std. $=0.86)$ and was followed by item (5) secondly in which it stated that: "The company is fast-growing towards achieving its main objectives " with a mean $(3.96$, Std. $=0.76)$, thirdly item (3) in which it stated that: "The company seeks for customers-satisfaction in a way beyond the size of the possibilities available " with a mean $(3.75$, Std.= 0.82$)$ and fourthly item (1) which stated that: "The company seeks to provide new services before its competitors " with a mean $(3.47$, Std. $=0.79)$.

\section{Discussion the Results}

The results of the study showed the role of entrepreneurship in achieving competitive advantage from the point of view of managers in small and medium enterprises in the Kingdom of Saudi Arabia, ranging between (3.64 - 3.96). The results of the study are similar to those of (Dalvi \& Ahangaran, 2014).This is in terms of the existence of a large relationship between entrepreneurship and competitive advantage in companies in Isfahan Governorate, but our study was conducted in Saudi Arabia.

The results also revealed the dimensions that have a positive impact on achieving competitiveness, including a study Zaridis (2016) as it is similar with my study, this study achieve competitiveness by proposing many tools and competencies as sources of advantage and as competitive and among these similar methods is the use of innovation or new technology, management techniques, and control of capital. 
Our study concurred with a study Haseeb et al. (2019), which showed the most important social and technological challenges that play a major role in improving the sustainable competitive advantage and sustainable business efficiency, but in our study, we showed the challenges and risks in general.

Murniningsih \& Hanafi (2020) study is similar to our study in terms of explaining one of the dimensions of entrepreneurship that has a positive impact on achieving competitive advantage, which is innovation, as it indicated the need to enhance the competitive advantage in small and medium-sized enterprises.

The results of this study are consistent with the results of a study Sulistyo and Ayuni (2020), the study showed that there is a significant impact on entrepreneurial capabilities and performance between entrepreneurship and social capital. The ability to innovate greatly enhances the performance and competitive advantage of small and medium-sized companies.

\section{Conclusion}

The sustainable competitive advantage is a major goal that all business organizations seek to achieve, as the basic problem that these organizations face is the problem of continuity and survival that they choose, which requires their possession of the factors supporting that, represented in the objectives, resources and able and motivated individuals, as well as the correct and necessary strategic options.

Using the descriptive, analytical approach relying on the questionnaire and distributing it for a sample which it consists of 100 administrators working in small and medium enterprises in Kingdom of Saudi Arabia. The results of the study showed, in general, that there is a positive relationship in the role of entrepreneurship in achieving competitive advantage in small and medium enterprises in the Kingdom of Saudi Arabia.

The study also showed that there are many means used to measure the competitive advantage and the quality of the services provided by providing services at competitive prices, providing their services before competitors, providing new services, and motivating the company to research and develop.

The study also indicated that the four dimensions (innovation, creativity, risk and pro-activity) have a positive impact on achieving competitive advantage.

From the point of view of managers in small and medium-sized companies, it appears that innovation takes place in several ways, the most important of which is the use of technology and the holding of training courses. As for the second dimension, which is creativity, it takes place through benefiting from creative workers, being keen on research and development, encouraging new ideas and innovating services.

Risks are also considered one of the dimensions that affect the achievement of competitive advantage, which is represented by the company's dangerous decisions, its high-cost projects and unsecured profits. As for the support activity, it was found that the provision of services includes new reservations, the company is quick to achieve its goals, and customer satisfaction exceeds the capabilities.

\section{Recommendations}

From the results of the study that were reached, several recommendations were made, represented by the following points:

For the company to review its mission and future visions to include all or some of the influencing elements, the most important of which are quality, research, development, attention to human resources, and meeting customer needs.

Increase focus on quality and work on adopting the concept of total and optimal quality.

The necessity for small and medium enterprises to provide the appropriate climate for knowledge sharing between the two leaders necessary to achieve competitive advantage by facilitating the process of communication between them and facilitating access to knowledge bases.

Focusing on creativity and innovation for workers through holding seminars and meetings, discussing issues related to work, quality and competitive advantage, benefiting from their ideas and opinions, and participating in decision-making processes.

Emphasis on the use of technological equipment, as well as the development of human resources for telecommunications companies, which is achieved by attracting specialized scientific and technical competencies and methods of selection and appointment. 


\section{References}

Oregon. (2010). An Introduction to Entrepreneurial Management. Retrieved from oregon.gov/das/docs/em-aboutthe-model.pdf.

Kuhn, B., Sassmannshausen, S. P., and Zollin, R. (2010). "Entrepreneurial Management" as a Strategic Choice in Firm Behavior: Linking it with Performance. In HTSF Conference in Twente, The Netherlands.

Alghanmi, A. O. (2020). Innovations as the Competitive Advantage for Small and Medium Enterprises: The Case for the Kingdom of Saudi Arabia.

Ab Rahman, N. A., \& Ramli, A. (2014). Entrepreneurship management, competitive advantage and firm performances in the craft industry: concepts and framework. Procedia-Social and Behavioral Sciences, 145, 129-137.

Dalvi, M. R., \& Ahangaran, A. G. (2014). Investigating the Effects of Entrepreneurship and Sustainable Competitive Advantage by Considering the Merits of Marketing and Innovation Capability: (Case Study: Isfahan Province Appliances Companies). International Journal of Academic Research in Business and Social Sciences, 4(3), 22226990.

Murniningsih, R., \& Hanafi, M. (2020, May). The Role of Entrepreneurial Leadership and ICT in Encouraging Competitive Advantage in SME's. In 1st Borobudur International Symposium on Humanities, Economics and Social Sciences (BIS-HESS 2019) (pp. 756-761). Atlantis Press.

Haseeb, M., Hussain, H. I., Kot, S., Androniceanu, A., \& Jermsittiparsert, K. (2019). Role of social and technological challenges in achieving a sustainable competitive advantage and sustainable business performance. Sustainability, 11(14), 3811.

Zaridis, A. D. (2016). The Relation Between Entrepreneur" s Characteristics and Competitive Advantage. A Roadmap to SME" s Success. International Journal of Emerging Research in Management and Technology, 5(9), 53-58.

Brown, T. E., Davidsson, P., and Wiklund, J. (2001). An Operationalization of Stevenson's Conceptualization of Entrepreneurship as Opportunity-based Firm Behavior. Strategic Management Journal, 22(10), 953-968.

Mckague, K., Wheeler, D., Cash, C., Comeault, J., Ray, E., \& Tambunan, T. T. H. (2011). Development of small and medium enterprises in a developing country. Journal of Enterprising Communities: People and Places in the Global Economy.

Baron, R. A., \& Henry, R. A. (2010). How entrepreneurs acquire the capacity to excel: Insights from research on expert performance. Strategic Entrepreneurship Journal, 4(1), 49-65.

Al Qudah, M. A. (2018). The impact of entrepreneurship initiatives in enhancing creativity and innovation. International Journal of Business and Management, 13(7), 157-168.

Burgelman, R. A. \& Kosnik, T. I. \& van den Pol, M. (1988). "Toward an Innovative Capabilities Audit Framework" in the book Strategic Management of Technology and Innovation, Burgelman and Maidique, editors. Irwin, Homewood, Illinois, pp: 31-44.

Covin. G \& Miles. P (1999). "Corporate Entrepreneurship and the Pursuit of Competitive Advantage", Baylor University ,1042-2587-99-2331.50

Antoncic, B. \& Hisrich, D. (2003) "Clarifying the Entrepreneurship Concept", Journal of Small Business and Enterprise Development, 10, pp: 7 - 24.

Christensen, K. (2004) "A Classification of the Corporate Entrepreneurship Umbrella: Labels and Perspectives", Int. J. Management Enterprise Development, 4(1), pp: 301-315.

Dess, G. G. \& Ireland, R.D. \& Zahra, S. A. \& Floyd, S.W. \& Janney, J.J. \& Lane, P.J. (2003). Emerging Issues in Corporate Entrepreneurship, Journal of Management 29 (3) , pp: 351 - 378

Zaid, M. F. M. A. (2013). Impact Of Entrepreneurship in Achieving the Competitive Advantage, An Emperical Research in Private Hospitals in Amman, Jordan (Doctoral dissertation, The University of Petra).

Bridge, S. (2017). Is "entrepreneurship" the problem in entrepreneurship education? Education + Training, 59(7/8), 740-750.

Rahatullah Khan, M. (2013). Mapping the entrepreneurship ecosystem of Saudi Arabia. World Journal of Entrepreneurship, Management, and Sustainable Development, 9(1), 28-54.

Padilla, A., \& Cachanosky, N. (2016). Indirectly productive entrepreneurship. Journal of Entrepreneurship and Public Policy, 5(2), 161-175.

Low, M. B. (2001). The adolescence of entrepreneurship research: specification of purpose. Entrepreneurship Theory and Practice, 25(4), 17-25.

Tracey, M., Vonderembse, M. A., \& Lim, J. S. (1999). Manufacturing technology and strategy formulation: keys to enhancing competitiveness and improving performance. Journal of operations management, 17(4), 411-428.

Li, S., Ragu-Nathan, B., Ragu-Nathan, T. S., \& Rao, S. S. (2006). The impact of supply chain management practices on competitive advantage and organizational performance. Omega, 34(2), 107-124.

Grant. R. (1998). "Contemporary Strategy Analysis: Concepts, Techniques, Application", Blackwell Publishers, Edition: 3.

Porter. M. (1985). Competitive Advantage, Creating and Sustaining Superior Performance. Free Press, New York. 
Thompson, J. \& Arthur, A. \& Strickland, A. \& Gamble, J. (2008). Crafting and Executing Strategy. 16th Edition. New York: McGraw-Hill/Irwin

Rungwitoo, T. (2012). The Simultaneous Effect of Individual Entrepreneurial Competencies on SMEs Competitive Advantage. In BAI 2012 Conference. April (pp. 3-5).

Javadi, P. (2012). Impact of E-service quality on sustaining competitive Advantage for Iranian IT firms.

Kotler, P. (2000). Marketing Management Analysis, Planning and Control. 5th Edn. Prentice-Hall, Englewood Cliffs, New Jersey.

Clulow, V., Gerstman, J., \& Barry, C. (2003). The resource-based view and sustainable competitive advantage: the case of a financial services firm. Journal of European Industrial Training.

Zaid, M. F. M. A. (2013). Impact of Entrepreneurship in Achieving the Competitive Advantage, An Emperical Research in Private Hospitals in Amman, Jordan (Doctoral dissertation, The University of Petra).

Sulistyo, H., \& Ayuni, S. (2020). Competitive advantages of SMEs: The roles of innovation capability, entrepreneurial orientation, and social capital. Contaduría y administración, 65(1), 10.

Epetimehin, F. M. (2011). Achieving competitive advantage in the insurance industry: The impact of marketing innovation and creativity. Journal of emerging trends in economics and management sciences, 2(1), 18-21. 